\title{
The Realistic Turn: Trends in Recent Australian Young Adult Fiction
}

\author{
Wendy Michaels
}

$\mathrm{D}$ uring the 1980s and 1990s Australian young adult fiction tended to be dominated by a genre of realism that featured the works of John Marsden as a kind of flagship. Robert Cormier's endorsement of Marsden as 'a major writer who deserves world-wide acclaim' was proclaimed in the marketing hype for Marsden's books. Many critics highlighted the literary realism of Marsden's works, as for instance. Watson (2001) who asserted that Marsden 'writes convincing, accessible first-person narratives about contemporary teenagers' (p. 468) and Saxby (1997) who described the Tomorrow books as a 'deservedly successful adventure' series 'in the Southall tradition' (p.227). The blurb on the flycover of The Third Day the Frost (1995), trumpets Marsden's 'reputation for writing realistic books that tackle tough issues', and media reviews chant similar mantras: 'action, adventure and heart-stopping danger', or 'tense. exciting and, most importantly, realistic'. Saxby (1993) has also praised Marsden's capacity to produce characters that emerge as 'real' with voices that 'so many of today's young adults would like to have' (p.694). These qualities are also lauded by critics of other realistic novels of the period, such as Sonya Hartnett's Sleeping Dogs, which was praised by the Children's Book Council of Australia Judges' Report as 'a tough story, evocatively told' (p.9). Craven (2003) has claimed the essence of realism is in embracing 'the shapes and smells of contemporary life' and in the 'entertainment value of someone else's experience, preferably of an intimate kind' (p.11) while Saxby (1997) has pointed out that social realism in Australian YA (young adult) novels has dealt with personal experiences such as '[d]ivorce, single parenting, delinquency. kids forced into homelessness, disruptive teenagers and disturbed primary school students' (p.267-8) and he has further suggested that the core of this realism lies in the selection of 'some significant experience from everyday life' and the exploration of its 'implications for the people involved' (p.248).

Marsden's representations of contemporary teenagers can be seen as somewhat problematic. His adolescents are commonly characters who have been traumatized or terrorized and some turn to suicide (as in Dear Miffy) as a solution to their situations. Marsden himself says that 'one of the most important moments in people's lives comes when they first experience betrayal by their parents' and he has represented this 'universal experience' of betrayal in So Much to Tell You (Magpies Vol 4, 2: 20 cited in Saxby 1993, p.693). Marsden also says, elsewhere, that he writes about 'the way corrupt fathers can damage their children' (cited in Mordue 2003, p.16) and he claims that '[m]ost of the stories of neglectful, insensitive or selfish parents [that appear quite often in his books].... are not made up (Marsden 2000, p.48). Whether depicting teenagers in relation to their family life, as for instance in Checkers, or in the wider social sphere, as for instance, in the Tomorrow series, Marsden tends to portray adults as the cause of the catastrophic madness of the world that teenagers inhabit and the teenagers as heroic in the face of this madness. The Tomorrow series, as Saxby (1997) points out, follows the activities of a group of 'young people who wage a guerilla warfare against the enemy' that has invaded Australia (p.227). Marsden (2000) confesses that he 'thought the book might be a chance to counter the bad press ... teenagers get' (p. 70). The message of the Tomorrow series, captured on one of the cover blurbs is: 'Now it's time to hit back, Now it's time to come out fighting'

Marsden's stories are presented as a slice of real-life in the sense that readers are taken into the story as if it were almost a documentary representation of a real world. In some books, Marsden achieves this through the diary or epistolary form while in others he uses the focalized first person narrator. Saxby comments (1997) that Marsden's use of ' a particularly astute and articulate focaliser' in Tomorrow When the War Began, for instance, enables him to 'chart the psychological development of the characters' (p.227). The confessional quality of the narratives convinces the reader of the truthfulness and universality of the story. The narrative perspective is often bleak and critical of the adult world. The narrator of Checkers, for instance tells us in the beginning: 'Life seems so fragile.... There are too many things beating at you, blowing at you, hurting you and leaving bruises. It's a miracle anyone survives to be a teenager. It's a miracle any teenager survives to be an adult' (p.3). At the end, ensconced in a mental institution, the narrator states, 'I think if I had anywhere to go they'd probably discharge me pretty soon, too. But with Dad not getting bail and Mum still not capable of looking after herself, let alone anyone else, they're not quite sure what to do with me.' (p.123) 
This kind of realism has not been without its critics. Marsden (2000) records some of the critical response to his works including that of his first publisher McVitty and a range of published reviews and personal responses from teachers and parents. Ireland has been particularly vociferous in her criticism (see for instance, Ireland 1995, 1996) condemning such books because the central characters are not 'transformed in some way by their experiences' (1997 p. 10). Scutter (1999) has criticized the depiction of post-apocalyptic dystopian worlds where 'adolescence is represented as beset with overwhelming pain, loneliness, difficulty in communication, [and] lack of love' (p. 122). Scutter is particularly critical of Marsden's Letters from the Inside which she describes as 'a book written within the generic code of realism but predicating the kind of dy stopian world that might be expected in post-apocalyptic disaster novels ${ }^{*}(p .18)$. Such criticisms reflect, of course, differing perceptions about the nature of the world and the capacity of literature to represent it. As Durante points out, 'Every children's story implicitly addresses broad questions such as: Is this world fundamentally a benevolent or malevolent place?'(p.13). Marsden's answers tend towards the malevolent and hence attract criticism from those who wish to assert the essential benevolence of the world.

However, Scutter also outlines a more substantial critical argument: this genre of realism masks its own constructedness since "realism can only ever be a bundle of strategies put together by language, and language is not a transparent or reflective glass' (p. 115). What Scutter is rightly pointing to is the way in which these novels, which I have labelled 'hard-core realism', position themselves as faithfully and truthfully presenting an essentialised, universalized adolescent reality which is, in fact, nothing more than a representation of a particular perception of reality situated socially, culturally and historically. Scutter also points to the notion that the kinds of adolescent experiences depicted in these novels are promoted as 'more authentic' than certain other kinds of adolescent experience such as 'growing up in a conventional family (p.116) and that the use of the word 'realistic' to describe these novels brings with it a set of values that suggests 'a naturalness and inevitability' to the events in the narratives.
Importantly, Scutter also argues that 'the genre [of realism] and its strategies change as perceptions of reality change - as they must do given the huge cultural and historic shifts that accompany the real lives of real people' (p.115). Her point here is that the genre itself will alter as perceptions of reality alter and values change. Perceptions of reality are changing in the new millennium, as indeed they have done in previous epochs. Craven (2003) charts some of the changes in perceptions of reality in relation to televisual realism. In the same vein, it is not surprising to find changes occurring in the genre of realism in the context of young adult fiction.

\section{Recent trends}

It would be premature to argue that fin-de-siècle twentieth century hard-core realism has disappeared from the Australian YA publishing scene: writers such as Marcus Zusak (Fighting Ruben Wolfe 2001) and Bill Condon (Dogs 2001) are still creating tough stories with grim endings set in dysfunctional worlds inhabited by ineffectual or evil adults, and told through the narrowly subjective focus of the adolescent first person narrator. Marsden's latest novel (While ILive: The Ellie Linton Chronicles) follows Ellie, the narrator of the Tomorrow series, into 'A new kind of fight' after the "devastating tragedy [that] has shattered any hope she ever had to reclaim her life, or herself' (Pan Macmillan 2003). Robinson (2003) notes that Marsden (whom she describes as 'not a happy-endings kind of writer') 'gets rid of the grown-ups' and places his adolescent characters in the face of 'violent conflict'. She is also critical of what she sees as 'premature publication' of this series book: '[T]here's a little sloppy repetition, a little clunky dialogue, some unconvincing scenes' (p. 13)

Nevertheless, shifts are occurring in this genre of realism. Books such as Ian Bone's The Song of an Innocent Bystander (2002) presents a grim hostage story without the narrowly positioned perspective of a single first person adolescent narrator but employing a range of metafictive devices such as flashback and interior monologue to present a more complex depiction of the events and their aftermath. Susanna Van Essen's The Tiger Project (2003), which presents the protagonist as a young girl confined to a wheel chair from birth after a series of botched medical operations failed to correct her congenital condition, positions the story within 
a wider context of moral questions about euthanasia and extinction and offers a kind of reconciliation and transformation as closure for most of the characters. Similarly, Celeste Walters' The Glass Mountain (2003) concludes with a transformation process for the protagonist after a turbulent series of events in a dysfunctional family, as a nominal member of a bikie gang and as the companion to the cancer-ridden eighty-four year old Essie, whose death he hastens with a morphine overdose.

While it is too early to determine how entrenched any pattern may become in Australian YA realism novels published since 2001 , this attempt to construct a retrospective narrative of trends identifies some common features that suggest an unfolding generic development. I am not trying to suggest a paradigm shift in the Kuhnian sense (1970) in which one world-view is replaced in a kind of seismic shift by another with the two being incommensurable. Indeed, there are instances of earlier YA fiction (eg Jenny Pausacker's What Are Ya?, Caroline Macdonald's Speaking to Miranda and Nadia Wheatley's The Blooding) that use similar complex metafictional and intertextual components to those I identify in the novels used in this study. Rather, I am suggesting that what we might be seeing here is a hybridization of the genre in the sense in which O'Neill (1992) describes the ways in which English syllabus documents incorporate features of different orientations on the subject English. O'Neill's notion of hybridity allows for the identification of features of different orientations in relation to their status as 'residual', 'dominant' or 'emergent' (p.11). While I would suggest that it is too early to apply this aspect of O'Neill's conceptual framework to the novels in this study, it may prove useful for future examination of trends in realistic fiction for young adults.

To illustrate the unfolding narrative of changes in direction for YA realistic fiction I have selected five novels published between 2001 and 2003 by five different publishers: Susanne Gervay's Butterflies (2001. Angus and Robertson). Alyssa Brugman's Walking Naked (2002. Allen and Unwin). Catherine Bateson's Painted Love Letters (2002. University of Queensland Press), Melina Marchetta's Saving Francesca (2003, Penguin: Viking), and Irini Savvides's Sky Legs (2003, Hodder Headline).
All are written by women and place a female protagonist at the centre of the story.

These five novels are all concerned in one way or another with significant problems and anxieties experienced by contemporary adolescents in their everyday lives - they are, in one sense, bildungsroman - coming of age stories. In Butterflies, the protagonist, Katherine, deals with the aftermath of the burns that she suffered in a childhood accident-multiple skin grafts, her damaged sense of body image and the fractures to the family that followed the accident as the father fled (later returning, repentant). In Painted Love Letters the protagonist, Chrissie, comes to terms with the approaching death of her father from cancer and the different ways in which her mother and grandmother deal with his death. In Walking Naked the protagonist Megan deals with the suicide of her friend Perdita, the dysfunctional family in which Perdita has grown up, and the ways in which group membership impacts on personal friendships. In Sky Legs, the protagonist Eleni deals with the trauma of her mother's death, her move to the mountains and her position as an outsider in the school and the associated bullying and mistreatment of her self and her friend, Pete, that emanate from their sexual and ethnic Otherness. In Saving Francesca the protagonist Francesca comes to terms with her change of school with the accompanying bullying and discrimination and her mother's depression. These issues are explored in the context of a variety of representations of families, schools and friendship groups.

These five novels depict worlds that are less than ideal-but, unlike the novels that I have termed hard-core realism, these worlds are not dysfunctional, dystopic or post-apocalyptic. Rather, they are the everyday worlds of contemporary families leading busy lives, with all the associated quotidian routines, pressures and traumas. The families are not merely idealized nuclear units: Katherine's family (Butterflies) lacks a father; Eleni's mother (Sky Legs) has died, and Francesca's mother (Saving Francesca) is suffering from chronic depression after a miscarriage Nevertheless, these families strive to function as best they can, often with the adolescent characters assuming some degree of responsibility for that functioning - although the adults are not represented as incapacitated or destructive. 
In Saving Francesca, for instance, Francesca assumes considerable responsibility for her younger brother and for the normal day-to-day running of the household - but so does her father alongside her.

Importantly, the novels do not position the adult characters as the cause of, or carrying the blame for, all the difficulties that the teenage characters encounter, as is found in the works of Marsden. Francesca's mother's clinical depression (Saving Francesca) is implicated in many of Francesca's difficulties - but Marchetta does not assign blame to the mother. Indeed the novel eventually offers an explanation of her mother's condition which Francesca herself comes to understand. Perdita's father beats her mother (Walking Naked) and although this contributes to Perdita's feelings of loneliness and despair, Brugman presents the parents as ineffectual and suffering rather than damaging and destructive. While Katherine's father has left the family after the accident in which she was badly burned at the age of three (Butterflies) Gervay offers both Katherine and the reader an explanation of his inability to cope with his own feelings - and the possibility of later reconciliation.

Moreover. all the novels point to the contributions that the young characters themselves make to the traumatic events or incidents in their lives - and this would seem also to be a departure of kinds from other realistic YA fiction. Indeed, the novels give us insight into the ways that the adolescent characters try to make sense of what is happening around them, take responsibility for their own actions and become active agents in their own lives. This common theme is signalled in the opening lines of Walking Naked: 'I am responsible for a great many things, but being put on detention for talking in History was not my fault (not technically, anyway)' Megan says at the outset. She eventually learns to accept responsibility for her life and for the choices that she makes, but not until she has experienced a serious dose of surviv or guilt when her friend Perdita takes her own life after Megan has rejected her. By the end of the novel, Megan is able to state that her biggest disappointment was 'that Perdita was not around to see that I too have learned the enterprise in walking naked' Katherine (Butterflies) also learns to take responsibility for her own decisions about her body as she struggles with skin grafts and even comes to understand why her father was not initially able to deal with the trauma of her accident. By the end, she confesses: '[T]here'll always be some scars. Not as many now. I can live with it.' Chrissie (Painted Love Letters) eventually learns, after her father's death, to accept that 'we were okay but not always'. All the female protagonists in these books become agents able to make moral choices for themselves and to recognize when others, adults or adolescents, do not. Some of them are even able to engineer situations that position others to face their own moral dilemmas. Eleni and Pete (Sky Legs) use their clowning skills to create a dramatic performance in which the bullying students are confronted with the consequences of their actions.

The adolescent characters are generally supported in their getting of wisdom by effective family relationships that are not idealized or sentimentalized as they might be in movies or soap operas. Francesca's father asserts 'I'm not a father in a movie', and while this has some echoes with Marsden's characters who say things such as 'This is real life', Francesca's father's statement occurs in a context of his acknowledgement of his vulnerabilities and frailties. While Megan (Walking Naked) initially sees her parents as 'predictable' and is critical of their loving relationship ('They even kissed in front of my friends'), she later comes to an understanding of their commitment to one another. Moreover, Brugman allows Megan's perception of her parent's apparently perfect relationship to include an awareness that it is not without its difficulties. While there are no perfect families depicted in these novels, the dominant value is the love that the parents have for their children and the concerns for their welfare.

In general, the teacher characters are also engaged in an enterprise of supporting and understanding the situations that the adolescent characters are negotiating. They are effectively acting as mentors for the adolescents on their journey to becoming adult. While there are some teachers who are presented as flawed-Ms Sloan's erratic discipline (Walking Naked), Mrs Finick's incipient racism (Sky Legs) and Mr Brolin's short fuse (Saving Francesca) - there are many representations of effective and affectionate teachers who are shown to be dealing with the vagaries of their own lives while at the same time interacting with the adolescent characters and their issues. Ms Cheetham allows Eleni and 
Pete (Sky Legs) to perform at the school concert, placing her trust in their capacity to offer the audience an entertaining and educative experience that will not compromise her authority. Mr Tilly's somewhat unusual method of supervision of detention (Walking Naked) engages and challenges Megan's perception of Perdita and enables her to grapple with her developing understandings, rather than simply promoting disciplinary or punitive measures

The presence of one or more adult mentor characters that guide the protagonist's journey to understanding is a central feature of these novels and marks one of the distinct differences with the hard-core realism where adults are more likely to be the cause of the problem, rather than assisting in the resolution. In Butterflies there are two mentor characters: the Professor who performs the skin grafts: and. symbolically perhaps, the Surf Life Saving Coach who treats Katherine 'like a father' and encourages her to pursue her talents despite her perception of her body and its scars. In Walking Naked the mentor characters are Professor Emmanuel Sabio who teaches poetry at university and Mr Tilly, the teacher that opens up Megan's understanding. In Painted Love Letters it is the school teacher, Mr Chapman who writes notes to Chrissie that help her come to terms with her impending loss and the ways in which the adults in her life are also dealing with the situation. Perhaps the most interesting manifestation of the mentor character occurs in Sky Legs, where guardian Angels look after Eleni's welfare in Byron Bay and back in the Blue Mountains when she is contemplating suicide. Interestingly, these Angels are not idealised angelic beings, but exhibit the same kinds of foibles and follies as human beings. Mihali, one of these guardian angels tells us. I knew I was in trouble when I saw Gabriel looking out over the mountains. This wasn't my friend Gabi, this was Chief Angel Trainer 54! He never came to earth, not unless something big was on.'

Interestingly, the only female mentor character occurs in Saving Francesca. Ms Quinn provides a refuge for Francesca, a quiet couch to which she can escape momentarily as she deals with the difficulties of home life and the situation of being marginalized as one of the few girls in the dominant male culture of the boys'school that has recently opened its senior years to girls. Feminist readings of these novels might find cause for concern at the Pygmalion-like feature that has the young adolescent female protagonists being shaped by adult males in novels written by female authors. In many of the instances cited, the mentor figure is a teacher or professor. In the case of Katherine (Butterflies) this shaping also includes the (re)construction of her body by the plastic surgeon professor as well as the reconception of her attitude to her life. While. on the one hand, it is possible to argue that the male gendering of the teacher offers a kind of affirmative action in a context where the feminisation of the teaching profession has been constructed as something of a problem, on the other hand, to situate the repository of knowledge primarily in male characters raises issues in relation to the outcomes for the characters. Taken in conjunction with the deaths or disabling of some of the mother figures in these novels this could be seen as a problematic representation.

Despite the loss and death that is a common feature of these novels (as it is in Marsden's stories) there is nothing grim or sinister in the resolutions. The reconciliations are not sentimental, fairy-tale 'happy ever after' endings. The immediate situations have been resolved for the moment as is common in literary realism, but there is more work to be done.

In Saving Francesca, the realization of her mother's emotional traumas is put into the context of her own difficulties as Francesca comes to new understandings about her parents and their past. She understands that her mother is not simply cured of her clinical depression and has still a long way to go as she notes the way her mother 'looks at her surroundings' as though 'she's been gone for a long time and doesn't know how to get back'. Similarly, in Butterflies, Katherine comes to accept her scarred body, the reappearance of her father, and the appearance of her grandparents in a Christmas celebration that signals the possibility of constructing a new life. But that new life is not a magical transformation for Katherine but a coming to terms with the best that can be done in the situation. 'There'll always be some scars. Not as many now. I can live with it', Katherine says as she looks to the future. Painted Love Letters also ends with a celebration - a wake that mourns not only the death of Chrissie's father but also celebrates the new life for all the characters. As Chrissie 
sips the champagne she says, 'I looked at my mother and she looked young, for the first time for months and Nan and Badger were on either side of her, as though there to catch her if she should fall'. In Sky Legs and Walking Naked there are deaths for the characters to deal with - and the need to come to terms with the loss and feelings of guilt at being left behind. Megan (Walking Naked) comes to understand the context of her survivor guilt as Professor Sabio expresses his own regrets about his relationship with Perdita: 'I wish that when Perdita came to me that day, I had told her that although she was not my daughter, I would have been proud if she had been', and Eleni (Sky Legs) understands not only her mother's death but the way in which she had lived her life. The endings are also beginnings for the main female adolescent characters as well as for other adult characters as they continue their projects of self (re)construction.

\section{Narrative Perspectives}

It is not only through their stories and resolutions that these new realism novels distinguish themselves from the hard-core realism of the previous decades but also in the ways in which they situate themselves as realistic fiction. While they may retain the first person narrator stance of the hard-core realistic novel - at least in parts of the stories - they tend to extend the scope of this subjective narrative position.

In Butterflies, the main narrator is third person omniscient, but Gervay also introduces a first person narrator as commentator so that the reader is given access to Katherine's inner thoughts. The first person narrator in the other four novels is the adolescent girl protagonist who tells us about the events and characters from her subjective viewpoint interspersed by dialogue that is mediated by her own voice. The narrative positioning is further manipulated so that we are given access to inner voices and thoughts, in an interior monologue represented as wishes, comments on events or instructions to self, commonly signalled in italic font. Francesca, for instance, tells us, 'So I walk in. Don't look at him. Don't look at him. Don't look at him. I look at him. 'It is also signalled in multiple first person narration that gives us access to the interior thoughts of a number of key characters including the mentor characters (.Sky legs)
There are also wider perspectives offered the reader through various metafictive devices. For instance, we are given unmediated access to the perspective of a range of other characters, particularly the mentor characters, through letters (Painted Love Letters), school assignments and essays (Walking Naked), and the imagined thoughts of other characters (Saving Francesca). and multiple first person narration. This use of shifting, multiple perspectives enhances the representation of the complexities of the events and characters, suggesting a different perception of reality.

Perhaps the most significant innovation in the new realism of these novels is the use of intertextual references to literary, artistic, musical and popular culture. Sometimes such references point to ironical positions or reveal a character's motives or thoughts. In Walking Naked, for instance, Megan comments on her use of the "'Jedi Mind Trick' as she plays power games with Ashley: 'These are not the droids you are looking for'. In Painted Love Letters, Dee shrieks, 'Are you the Addams family or something!' revealing her lack of understanding of the situation when she sees the coffins that Chrissie's father is painting; and the character Badger provides a reference point to Wind in the Willows as a character who provides wise counsel for Nan.

There are many references to literary works that the characters encounter in school, such as the poetry of T.S.Eliot and Cormier's novel The Chocolate War, as well as works individual characters encounter through their own explorations - Perdita's references to films such as Citizen Kane and the poetry of Plath and Yeats, for instance. Some of the intertextual references occur in the form of the naming of a work and discussion of its key ideas and in one sense it is not surprising to find such references in stories set in secondary schools. However, these references are not simply gratuitous or merely techniques to establish setting and character; they are emblematic devices to explore and illuminate key issues explored in the stories. For instance, in the first chapter of Butterflies, Jessie and Katherine refer to Frankenstein, Dracula and Romeo andJuliet in the opening dialogue, introducing the motif of Katherine's perception of herself as a beast and her desire to be loved; while in Saving Francesca, Anna Karenina is referred to in the early dialogue, introducing the motif of the tragic fate of a 
woman in love with a socially inappropriate lover-which is at the core of her mother's dilemma.

The poetry in particular is used to highlight ways in which the female protagonists come to terms with the tribulations of their lives. Brugman, who takes her title (Walking Naked) from Yeats' poem, 'A coat', uses many poems emblematically to highlight the stages in Megan's developing understanding. For instance, in the tutorial class that Perdita and Megan attend at the university, the topic for discussion is Plath's poem 'The Thin People' and the tutorial discussion highlights the poem's issue of survivor guilt - a key issue for Megan after Perdita takes her life as well as for Megan as she sits in the class aware of her own lack of knowledge and understanding of poetry and the wider world. Later, in the Community Poetry Appreciation Class when her father reads a poem by e.e.cummings, Megan finally comes to understand the love that her parents have for each other. The entire text of Rosetti's poem, 'When I am dead' prefaces Megan's first person reportage of Perdita's death, 'Perdita took her life on a Tuesday'. thus shaping the way in which we view Megan's response to her friend's suicide.

But it is not simply the literary and artistic works of others that are referred to or reproduced in these novels. Chrissie (Painted Love Letters) makes her own art-work and various characters write their own poetry. The inclusion of the characters' poems both interrupts the narrative flow and adds communicative depth to the narrative voices. As readers we are re-positioned by the spatial dimensions of the verse - the ways the words on the page draw attention to themselves in the flow of the narrative. This valorising of art and literature suggests their importance in shaping the characters' understandings. Megan in Walking Naked learns this as she writes her final poems to Perdita, and although she angrily says that 'most poems are a joke' and 'riddled with secret messages' she discovers that they also contain powerful truths; while in Painted Love Letters Chrissie says. 'I wanted to think I was artist enough to do what my father would have done'. The exchange of poems in Sky Legs allows the two characters, Eleni and Pete to come to understand what they both have in common: their sense of difference and their pain. Pete expresses the way he shuts out the pain ('nothing much/you tell yourself/and don't see the shutters/ close/ across your eyes'), while Eleni's poems express her belief in the angels that have looked after her ('suddenly/letters arrived/mum whispered/dad laughed again/and my heart turned over/from its winter sleep').

There is a problematising of artistic works and their relationship with life in these books. In Saving Francesca, for instance, the discussion of the play Macbeth by Francesca and Mr Ortley, and by the girls on the bus, highlights the key issue of patriarchal institutional structures and cultural practices that oppress women ('It's an exposé of how strong-minded women either end up going insane or being clobbered'), and brings to the fore the relationship between art and life ('It's just a play'). The play that is performed as the climax to Sky Legs is represented in the book as a script: 'Scene I. The lights go down and Eleni runs across the stage.' The play that Eleni and Pete have devised is a revenge action for the discrimination and bullying that they have encountered. It is presented as a play within the story in a fictional context of a fascist regime in the ' $\mathrm{Land}$ of $\mathrm{O}$ '. but presented in a dramatic form that requires audience participation that is restitutive for all characters.

The closure of each of the books contains a kind of coda: each female protagonist reflects on the meanings gleaned from the experiences and articulates her understandings almost as artistic manifestoes. The key understanding gleaned for all these protagonists is of hope for the future that comes from understanding the past: Francesca admits that 'for the first time all year I went to school with hope in my heart' (Saving Francesca); Katherine tells her mother, '[Y]ou've taughtme hope'. and admits to the reader, 'I'm not scared any more' (Butterflies); Megan speaks of feeling 'a kind of restrained exhilaration about my future' (Walking Naked); Chrissie confesses that she 'knew now everything about love and death, everything that [she] needed to know' (Painted Love Letters); and Eleni (Sky Legs) 'was sure she' $d$ felt a shift, as if something black had been lifted from the place, some dense energy that covered it had been released, letting the ghosts of the past free and making room for a different future'. Each of the main characters has learned that they have to engage in the on-going task of self-construction and that this project requires an understanding of the past in order to move into the future. In Sky Legs, Pete represents his understanding in his final 
(rhyming) poem: 'Ice has thawed/Seasons turned/Inner dragons/Singed and burned', while for Eleni the coda is presented in non-rhyming verse: 'I hear and move slowly to the wind's call/happy I waltz on a mountain top/with a boy wearing a dress'. For Megan (Walking Naked) the coda has a confessional quality to it: "Perdita was the most uncompromising person I have ever met, and when I think of her now, that is the quality I admire most. It's also the quality that made her choose to die. I think she gave up on the world, and gave up on me, too soon.

Interestingly, Marsden's most recent novel, While I Live: The Ellie Chronicles, also includes an 'Epilogue' that works as a kind of coda. Ellie confesses, 'It gave me more hope that I could make a go a things by myself', but it is a hope tempered by her allusion to The Little Engine That Could ('I think I can, I think I can, I think I can') and her final comments, 'I'm just me, just Ellie, sitting at the kitchen table, trying to make my life work'. The contrast is clear: in Marsden's novel, the adolescent has to do it alone: in the five novels discussed here, the adolescent protagonists are supported in making their lives work

If the features of the novels discussed above can be seen as constituting a new trend in the genre of Australian young adult realistic fiction, the question must be asked: how might we explain such a trend? Is an explanation in terms of the female authors sufficient to account for the patterns? Moi $(1985 / 2002)$ in surveying the debates about 'écriture feminine', notes that Kristeva admits that it is possible 'to distinguish various recurrent stylistic and thematic peculiarities in writing by women' but impossible to determine whether they can be 'ascribed to a "truly feminine specificity"' (p. 163). Moi correctly resists 'homogenous, non-contradictory, non-conflictual models of subjectivity' (p. 177)

An essentialising explanation for the features identified in these realistic novels such as 'écriture feminine' would clearly not stand up to critical examination and certainly not hold sway in the current context of young adult fiction in the Australian publishing scene. The style that I have called 'hard-core' realism was produced not only by male writers but also by female writers such as Sonya Hartnett, while male writers such as Steven Herrick (The Simple Gift) and Simon French (Where in the World?) are producing stories that share the features identified in this analysis. Another possible explanation might be developed from an examination of the publishing houses producing these works. Given that the five novels are published by five different publishing houses, can this been explained as a marketing manoeuvre to capture a new niche adolescent market? While this might be an attractive notion, particularly when other books from other publishing houses are added to the sample, it is too facile an explanation for the phenomenon. Perhaps the trend can be explained as a synchronic movement as different publishers position their YA lists in tune with a zeitgeist that posits young people as 'optimistic about the future' (Nixon 2003, p 1). There seems to be something more complex in the patterns than these simple explanations would suggest.

In the commentary on Dear Miffy, Marsden says that in his ending to this novel he wanted to pose the questions:

\section{Why do we read fiction? Is it just an escape, as a lot of people suggest, or are there more complex motivations? \\ (2000, p. 116)}

Part of the answer that Marsden offers to his own questions positions the reader as a voyeur who explores the innermost rooms of people's lives"' (p.117). Marsden's interest is focused on what he sees as the adolescent's 'search for a new identity built on the realization that one's identity as a child has started to dissolve' (Marsden 2000, p. 19). This argument is based on the Enlightenment assumption of 'persons as unique unified agents' (Barker 2000, p. 168). Marsden implies that the unified childhood identity is replaced by a unified adolescent identity and the fiction traces the process of change. This argument not only sidesteps the issue that characters in books are not persons but artistic, literary constructions, but it also ignores more recent challenges to the notion of the Cartesian self as a fixed unified identity that have emanated from the work of theorists such as Foucault who posits the self, itself, as a discursive construction and 'agency as a socially constituted capacity to act' (Barker 2000, p. 182) or Lacan and Bakhtin who 'see the formation of subjectivity as being dialogical' (McCallum 1996, p.17). McCallum's explications of the significance of Lacanian and Bakhtinian understandings of the social construction of subjectivity as a central aspect of 
the developmental process of childhood to adulthood(1996, 1999) have implications for these coming of age novels which represent a different conception of subjectivity to that implicit in Marsden's works. Unlike Marsden's unified self, in these novels there is a sense of the characters on-going project of social construction of subjectivity and identity. Nevertheless Marsden's question about why we read fiction is pertinent to the trend identified in the five novels discussed in this paper and may perhaps point in the direction of possible explanations.

These novels can be categorised as bildungsroman, but they offer a different kind of understanding of the nature of the getting of wisdom or coming of age. In all the works examined there is an elevation of the importance of the arts and literature, as the characters engage with artistic and literary works as part of the process of (re)constituting themselves as agents in their own lives. The getting of wisdom is positioned within a context in which the characters have to constantly renegotiate their identities, their selves. They draw not only on their life experiences to do so. but also on the created works of other selves - in art and literature - as essential tools in their projects of self (re)constitution.

These novels suggest a somewhat different answer to the question, 'Why read fiction?', from that given by Marsden. Rather than voyeuristically viewing other selves, fiction, literature, art, all offer the individual resources for the ongoing project of the construction of self-identity. Whereas the reader of hard-core realism is invited to cast the gaze on the unified selves of adolescent characters as they deal with the traumatic events of the 'real world', the new realism invites the reader to become complicit in the aesthetic construction of self-identity through the narrativising of the self. This fetishisation of the arts and literature constitutes an 'aestheticization of the quotidian' (Bertens 1995, p.214) or an 'aestheticization of life' (Featherstone 1991, p.45) itself. The characters use the experiences of literature and life in the on-going process of constituting their self-identities. By employing metafictive devices and intertextuality these writers offer readers a more complex view of the realistic world of the characters that are engaged in the constant process of becoming. There is hope for the future because the characters become agents in the on-go- ing project of construction and (re)construction of their own narratives of identity. The readers are not invited to be engaged as voyeurs but as active agents in the project of identity construction.

The pattern in YA realistic fiction identified in these five novels signals a change in the conception of the self and the ways in which that self is constantly reconstructed. In the process of negotiating the construction and reconstruction of the individual self the character not only draws upon lived experience but also interacts with representations of experience in art, music and literature. The readers not only observe this process in and through the fictional characters. but also use the experience of reading to further the project of self-constitution in their own lives.

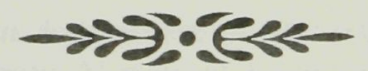

\section{REFERENCES}

Barker, Chris (2000) Cultural Studies: Theory and Practice. London, Sage Publications.

Bateson, Catherine (2002) Painted Love Letters. St Lucia, University of Queensland Press.

Bertens, Hans (1995) The Idea of the Postmodern: A History. London and New York, Routledge.

Bone, Ian (2002) The Song of an Innocent Bystander. Melbourne, Penguin.

Brugman, Alyssa (2002) Walking Naked. Crows Nest, Sydney, Allen and Unwin.

Children's Book Council of Australia Judges Report (1996)

Condon, Bill (2000) Dogs. Sydney, Hodder Headline.

Craven, Peter (2003) 'Bless this house', The Australian, 20 June, p.11.

Durante, Dianne (2003) 'The best of all possible worlds', The Australian, 20 June, p.13.

Featherston, M. (1991) Consumer Culture and Postmodernism. London and Newbury Park CA, Sage Publications. 
French, Simon (2003) Where in the World? Surry Hills. NSW, Little Hare Books.

Foucault, Michel (1980) Power/Knowledge. New York. Pantheon

Foucault, Michel (1984) 'What is the Enlightment?' in P. Rabinow (ed) The Foucault Reader. New York, Pantheon.

Gervay, Susanne (2001) Butterflies. Sydney, Angus and Robertson

Hartnett, Sonya (1995) Sleeping Dogs. Ringwood, Victoria, Viking

Herrick, Steven (2000) The Simple Gift. St Lucia Queensland, University of Queensland Press.

Ireland, Jill (1995) 'The Australian book awards for older readers', Education Monitor 5, 3 : 23-28.

Ireland, Jill (1996) 'Balance or bias? HSC English texts in NSW', Education Monitor 6, 2: 1821.

Ireland, Jill (1997) 'What our children read: Are there no ethical boundaries?' Journal of Education Tasmania, Autumn, pp.8-10.

Kuhn. Thomas (1970) The Structure of Scientific Revolutions. Chicago, University of Chicago Press.

Marchetta. Melina (2003) Saving Francesca. Camberwell Victoria, Penguin

Marsden, John (1996) Checkers. Sydney, Macmillan Australia

Marsden, John (1997) Dear Miffy. South Melbourne Victoria, Macmillan.

Marsden, John (1992) Letters from the Inside. Chippendale NSW, Pan Macmillan.

Marsden, John (2000) Marsden on Marsden: The Stories behind John Marsden's Bestselling Books. Sydney, Pan Macmillan.

Marsden, John (1999) [1987] So Much to Tell You. Port Melbourne Victoria, Lothian.
Marsden, John (1995) The Third Day, The Frost. Sydney, Macmillan.

McCallum, Robyn (1996) 'Other selves: subjectivity and the Doppelgänger in Australian adolescent fiction', in Bradford, Clare (ed) Writing the Australian Child. Nedlands, Western Australia, University of Western Australia Press in association with Centre for Research in Cultural Communication, Deakin University, pp. 17-36.

McCallum, Robyn (1999) Ideologies of Identity in Adolescent Fiction: The Dialogic Construction of Subjectivity. New York, Garland.

Moi, Toril (1985/2002) Sexual/Textual Politics. London, Routledge.

Mordue, Mark (2003) 'The secret life of us', Australian Author 35, 1: 8-16.

Nixon, Sherill (2003) 'It's generation Y worry, be happy', The Sydney Morning Herald. Tuesday June 17, p. 1.

O’Neill, Maureen (1992) 'Contested ground: English syllabus and examination practices in Western Australia', Curriculum Perspectives 12, 1, April

Pan (2003) Pan Macmillan Australia Online: 'John Marsden' accessed at www.panmacmillan. com.au/johnmarsden/index.htm

Savvides, Irini (2003) Sky Legs. Sydney, Hodder Headline

Saxby, Maurice (1993) The Proof of the Pudding: Australian Children's Literature 1970-1990. Sydney, Ashton Scholastic.

Saxby, Maurice (1997) Books in the Life of a Child: Bridges to Literature and Learning. Melbourne, Macmillan Education.

Scutter, Heather (1999) Displaced Fictions: Contemporary Australian Fiction for Teenagers and Young Adults. Melbourne, Melbourne University Press. 
Van Essen, Susanna (2003) The Tiger Project. Sydney, Pan Macmillan.

Walters, Celeste (2003) The Glass Mountain. St Lucia Queensland, UQP.

Watson, Victor (2001) The Cambridge Guide to Children's Books in English. Cambridge, Cambridge University Press.

Zusak, Markus (2000) Fighting Ruben Wolfe. New York, Scholastic.

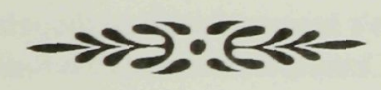

\section{BIOGRAPHICAL NOTE}

Dr Wendy Michaels lectures in the School of Humanities at the University of Newcastle, teaching courses in Creative Writing and Children's Literature. Her current research interests are in emerging patterns and trends in the young adult novel. Her recent research has examined representations of gender, identity and childhood in recently published works and the appropriation of oral and dramatic traditions in the developing genre of the verse novel. She has also published poetry, plays, stories and a picture book for children. 